\title{
TAF15/NR4A3 Fusion Gene
}

National Cancer Institute

\section{Source}

National Cancer Institute. TAF15/NR4A3 Fusion Gene. NCI Thesaurus. Code C99501.

A fusion gene that results from a chromosomal translocation $\mathrm{t}(9 ; 17)(\mathrm{q} 22 ; \mathrm{q} 11)$ which

fuses exon 6 of the TAF15 gene to the entire coding sequence of the NR4A3 gene. This rearrangement is associated with extraskeletal myxoid chondrosarcoma. 